\title{
Job performance of resident doctors in government teaching hospitals in South-western Nigeria
}

\author{
Maria Ehioghae \\ Babcock University, Ogun State, Nigeria \\ E-mail: ehioghaem@babcock.edu.ng \\ Ezinwanyi Madukoma \\ Babcock University, Ogun State, Nigeria \\ Vincent E. Unegbu \\ Babcock University, Ogun State, Nigeria
}

\begin{abstract}
The study explores the job performance of resident doctors in government teaching hospitals in Southwestern Nigeria. Job performance serves as a gauge to measure the health of organizations. The study adopted the descriptive research design to investigate six out of the seven government teaching hospitals in Southwestern Nigeria. Total enumeration was used to administer 792 copies of questionnaire to the resident doctors but 636 were returned for data analysis, making the response rate to be $80.3 \%$.Data obtained were analyzed using descriptive statistics (frequency counts, percentage, mean and standard deviation). Findings revealed that the job performance of resident doctors in the government teaching hospitals in was remarkably high. There were, however, staff shortages which invariably led to heavy workloads and stress among the resident doctors. The opportunities for advancement were also limited. It was, therefore, recommended that the management of the teaching hospitals should increase the staff strength of the resident doctors to avoid stress and burnouts. The workplace environment should be improved by providing opportunities for the doctors to advance their careers.
\end{abstract}

Keywords: Job performance, government teaching hospitals, resident doctors, Southwestern Nigeria

\section{Introduction}

Teaching hospitals are generally expected to render quality and prompt service delivery to their patients but this is highly dependent on the caliber of resident doctors who, to a large extent, determine the quality of services the patients receive. Notably, resident doctors play an important role in achieving the institutions' goals and objectives. But resident doctors in teaching hospitals may sometimes be burdened with the heavy workloads of providing quality service delivery to the community (Yakasai, Ugwa\&Abubakar, 2013). In government teaching hospitals in Southwestern Nigeria, like any other health institutions, much premium is placed on the doctors' performance, particularly in areas relating to proper clinical diagnosis, maintaining the confidentiality of patients, ensuring a good relationship between colleagues and patients and accountability for any course of action in the organization.

To sustain a high level of effectiveness in job performance, resident doctors would need a conducive environment such as call rooms and welllighted environment aside from other motivating factors like good pay, job security, and the chances of promotion (Ogunnubi, Ojo, Oyelohunnu, Olagunju \& 2018). Sometimes, when the working environment and other factors mentioned above are lacking or inadequate they may affect job performance or even lead to industrial action strikes and the lives of the 
Maria Ehioghae, Ezinwanyi Madukoma and Vincent E. Unegbu: Job performance of resident doctors in government teaching hospitals in South-western Nigeria

patients in the community that they render services to will be in danger.

\section{Literature review}

Job performance is the execution of any activity or a pattern of behavior of workers that either contributes to or negates productivity. It is the employee's total contribution to the organization and it is composed of all the individual actions that support or detract from the organization's goals to varying degrees (Campbell \& Wiernik, 2015; Saka \& Haruna, 2013).It is pertinent to note that job performance is one of the most important factors within an organization, particularly in maintaining quality service. This is especially the case for resident doctors whose job performance is tied to the roles, duties, and responsibilities they render to the patients. In other words, when a doctor provides patients with prompt attention, it is indicative of their job performance.

In the context of health institutions, job performance may refer to how resident doctors carry out tasks, duties, and responsibilities associated with a particular job. The performance of these roles or duties is geared towards the attainment of the goals and objectives of the health organization. In a sense, job performance is an indicator for measuring organizations' or institutions' performance, including that of government teaching hospitals. Even though some researchers observed that job performance can be enhanced by training and development, there are counterproductive work behaviour such as workplace aggression, tardiness, and absenteeism that negatively impinge on job performance of employees (Amudha, Hamidah, Annamma \& Ananth, 2018; Alagaraja \& Shuck, 2015).

Some researchers view job performance as having two dimensions, namely, behavioral and outcome aspects (Okorie, 2019; Shaju \& Subhashini, 2017). The behavioral aspect refers to what people do at work, the action itself while the outcome aspect refers to the result of the person's behavior. The behavioral and outcome aspects are important and related. It means that both thebehavioral and outcome aspects of job performance lead to the improvement of an organization as well as reveal the productivity of employees. But Campbell (1990) provided eight measuring indicators, namely, job-specific task proficiency (behaviors that an individual undertakes as a part of a job); non-job-specific task proficiency (tasks that do not pertain only to a particular job); communication (includes formal and informal oral and written presentations to various audiences in many different jobs in the workforce); demonstrating effort (consistency or perseverance and intensity of the individuals to complete the task); team performance (acting as a good role model, coaching, giving advice or helping to maintain group goals); clinical leadership (responsible for meting out rewards and punishments); personal discipline (individual would be expected to be in good standing with the law); and attendance (setting an organizational goal or responding to external stimuli to assist a group in achieving goals of the organization). All these eight indicators for measuring performance are relevant to the job performance of resident doctors.

Diagnosis is a vital element of a resident doctor's expertise in medical practice and it is based on knowledge and strong assessment skills. Importantly, resident doctors work collaboratively with the health teams to provide optimal care. But to attain effectiveness and efficiency the doctors will need to possess relevant cognitive knowledge and skills which are important for their job performance. In line with evidence-based medicine (EBM), these skills and knowledge involve clinical decision-making and clinical judgment made by the doctors to decide specific aspects of care, such as diagnosis, choice 
Maria Ehioghae, Ezinwanyi Madukoma and Vincent E. Unegbu: Job performance of resident doctors in government teaching hospitals in South-western Nigeria

of test and how to carry out a clinical assessment of patients (Graham, Fional \& Colin, 2011; Khalifa, 2014).

Generally, doctors should have the interest to listen to patients and respect their views and be able to give patients information in a way they can understand. Also, patients' right to be fully involved in decisions about their care should be respected. For this to happen, doctors are, to be honest, and trustworthy; they should ensure that their personal beliefs do not prejudice the patients' care. In other words, respect for patients is a critical ingredient for their care. Unfortunately, researches seem to indicate that resident doctors are not doing enough in the area of their clinical services, particularly in the aspect of treating patients with respect and politely (Douglas, Nicol \& Robertson, 2011; Olsen \& Neale, 2005). Other researches show that nonchalant attitudes like tardiness and absenteeism have been implicated for low job performance in some government teaching hospitals in Nigeria (Aacharya \& Varghese, 2016; Akokuwebe \& Adekanbi, 2017).

The art of medicine is, to some extent, a function of communication. Resident doctors often work all day with patients from all walks of life and ages, asking them questions about their health and reporting these findings. In a study conducted by the Mayo Clinic in Arizona and Minnesota from 2001 to 2002, it was found that strong communication skills were among the most significant in career success (Neeli, Leonard, Keith \& William, 2006). Even though doctors must understand how to treat their patients and which procedures will be used, it is difficult to contest the view that doctors who communicate well can perform effectively and efficiently; they can identify patients' problems more rapidly and accurately. When applied to resident doctors, it is easy to identify a link between the way they communicate and their productivity or effectiveness.
In the context of health care organizations, resident doctors are expected to act as a good role model and to foster a team spirit. Managing the health conditions of patients is usually not done alone. It requires collaboration and cooperation among health care providers. Where there is a lack of good interpersonal relationships, the resident doctors cannot perform as expected and the absence of team spirit could even be counterproductive (Bello, Ajayi \& Asuzu, 2018; Ogunnubi, Ojo, Oyelohunnu, Olagunju \& Tshuma, 2018). The ability to work as a team in meeting a set goal is of high value in the health institutions. Also, personal discipline is of high value to the doctor as a professional. When doctors violate the ethics of the profession they will likely be exposed to litigations. Therefore, resident doctors are expected to be humane, forthright, respectful, and thorough. Finally, in regards to attendance resident doctors, like other professionals, should be reliable, consistent, and thorough in carrying out their responsibilities. Of all professions, the medical profession should be characterized by workers who are dependable and trustworthy.

\section{Objectives of the study}

The objectives of the study are to:

1. determine the level of job performance of resident doctors in government teaching hospitals in Southwestern Nigeria; and

2. identify the barriers to job performance of resident doctors in government teaching hospitals in Southwestern Nigeria.

\section{Research questions}

The following research questions guided the study:

1. What is the level of job performance of resident doctors in government teaching hospitals in South-western Nigeria?

2. What are the barriers to job performance of resident doctors in 
Maria Ehioghae, Ezinwanyi Madukoma and Vincent E. Unegbu: Job performance of resident doctors in government teaching hospitals in South-western Nigeria

government teaching hospitals in Southwestern Nigeria?

\section{Methods}

The study used the descriptive research design to investigate the job performance of resident doctors in government teaching hospitals in Southwestern Nigeria. The population of this research consisted of 792 resident doctors working in government teaching hospitals in Southwestern Nigeria. Southwestern Nigeria is one of the six geo-political zones and made up of six states are Lagos, Ondo, Osun, Ogun, Ekiti, and Oyo. The government teaching hospitals in the region are: (i) College of Medicine, Ekiti State University, Ado-Ekiti, (ii) Ladoke Akintola University Teaching Hospital, Ogbomoso, (iii) Olabisi Onabanjo University Teaching Hospital (OOUTH), Sagamu, Ogun State, (iv) Lagos University Teaching Hospital, (LUTH), Idi-araba, Lagos State, (v) Lagos State Teaching Hospital, (LASUTH), Ikeja, Lagos State, (vi) Obafemi Awolowo University
Teaching Hospital, lle-lfe, Osun State and (vii) University College Hospital (UCH), Ibadan. Oyo State. As a result of the manageable size of the resident doctors in these teaching hospitals, total enumeration was used. A total number of seven hundred and ninety-two (792) questionnaire were used to collect data from the resident doctors in all the teaching hospitals in the region, except Olabisi Onabanjo University teaching hospital (OOUTH), Sagamu, Ogun State where the researcher was not allowed to collect data for reasons best known to the hospital management. Out of the 792 copies of questionnaire administered, 636 copies were retrieved for data analysis which constituted $80.3 \%$ of the response rate. Descriptive statistics (frequency counts, percentage, mean and standard deviation) were used to answer the research questions.

\section{Findings}

Therespondents' analyzed demographic data are shown in Table 1 
Maria Ehioghae, Ezinwanyi Madukoma and Vincent E. Unegbu: Job performance of resident doctors in government teaching hospitals in South-western Nigeria

Table 1: Demographic characteristics of the respondents

Distribution of respondents by gender

Gender

Male

Female

Total

Age

25-30yrs

31-40yrs

41-50yrs

51-60yrs

Total

Marital Status

Married

Single

Separated

Widowed

Total
Frequency

416

220

636

Distribution of respondents by age

Frequency

124

405

103

04

636
Percentage
65.4
34.6
100.0

Percentage

19.5

63.7

16.2

0.6

100.0

Distribution of respondents by marital status

Frequency

441

Percentage

69.4

30.1

0.3

0.3

100.0

191

02

636
Educational qualification MBBS/MBCHB

Masters

$\mathrm{PhD}$

Missing Values

Total

Designation

Junior resident

Senior resident

Total

Distribution of respondents by educational qualification

Frequency

484

93

06

53

583
Percentage

76.6

14.6

0.9

8.3

100.0

Percentage

59.3

40.7

100.0
As shown in Table 4.1, four hundred and sixteen $(65.4 \%)$ of the respondents were males, while 220 (34.6\%) were females. This clearly reveals that the hospitals are dominated by male physicians. The table also shows that $124(19.5 \%)$ of the respondents were within the age range of $25-30,405(63.7 \%)$ were within the ages of $31-40,103(16.2 \%)$ were within the ages of 41-50, while $04(0.6 \%)$ were within the ages of 51-60. From the result, therefore, it could be concluded that the majority of the resident doctors in government teaching hospitals in Southwestern Nigeria were still in their prime age; that is, 31-40 years which is the stage noted for useful contributions to the organization.

The table reveals that $441(69.4 \%)$ of the respondents were married, 191 $(30.1 \%)$ were single, $02 \quad(0.3 \%)$ were separated, while $02(0.3 \%)$ were widowed. Thus there were more married respondents than singles. The reason for this may be because they were all adults marriageable age. The table also showed 
Maria Ehioghae, Ezinwanyi Madukoma and Vincent E. Unegbu: Job performance of resident doctors in government teaching hospitals in South-western Nigeria

that $484(76.1 \%)$ of the respondents' highest qualification were MBBS/MBChB, 93 (14.6\%) were Masters, $0.6(0.9 \%)$ were Ph.D., while $53(8.3 \%)$ were missing. From the table, therefore, it is clear that most of the respondents were MBBS/MBChB holders. This indicates that for many of the respondents there is still room to acquire more professional qualifications to enhance their professionalism.

Table 1 shows that 377 (59.3\%) of the respondents were junior resident doctors, while $259(40.7 \%)$ were senior resident doctors. It takes several years to become senior resident doctors hence those in the rank of senior resident doctors will were fewer than junior resident doctors.

Research question 1: What is the level of job performance of resident doctors in teaching hospitals in Southwestern Nigeria?

This question is answered with the data in Table 2.

Table 2: Level of job performance of resident doctors in teaching hospitals

\begin{tabular}{|c|c|c|c|c|c|c|}
\hline Job Task Proficiency & $\begin{array}{l}\text { Strongly } \\
\text { Disagree }\end{array}$ & Disagree & Agree & $\begin{array}{l}\text { Strongly } \\
\text { Agree }\end{array}$ & Mean & Std \\
\hline $\begin{array}{l}\text { I carry out physical } \\
\text { examination of patients in my } \\
\text { hospital }\end{array}$ & $04(0.6 \%)$ & $02(0.3 \%)$ & $159(25.0 \%)$ & $471(74.1 \%)$ & 3.72 & 0.49 \\
\hline $\begin{array}{l}\text { I conduct medical history in } \\
\text { my hospital }\end{array}$ & $04(0.6 \%)$ & $04(0.6 \%)$ & $173(27.2 \%)$ & $455(71.6 \%)$ & 3.70 & 0.51 \\
\hline $\begin{array}{l}\text { I carry out patients' medical } \\
\text { diagnosis in the hospital }\end{array}$ & $04(0.6 \%)$ & $16(2.6 \%)$ & $172(27.0 \%)$ & $444(69.8 \%)$ & 3.66 & 0.56 \\
\hline $\begin{array}{l}\text { I carry out the job of clerking } \\
\text { of patients effectively }\end{array}$ & $04(0.6 \%)$ & $24(3.8 \%)$ & $172(27.0 \%)$ & $436(68.6 \%)$ & 3.64 & 0.59 \\
\hline $\begin{array}{l}\text { I carry out clinical assessment } \\
\text { of patients }\end{array}$ & $02(0.3 \%)$ & $32(5.2 \%)$ & $155(25.3 \%)$ & $423(69.2 \%)$ & 3.63 & 0.59 \\
\hline $\begin{array}{l}\text { I carry out clinical decision } \\
\text { making of patients in the } \\
\text { hospital }\end{array}$ & $02(0.3 \%)$ & $24(3.9 \%)$ & $191(30.8 \%)$ & $403(65.0 \%)$ & 3.60 & 0.58 \\
\hline $\begin{array}{l}\text { I carefully prescribe drugs to } \\
\text { patients in the hospital }\end{array}$ & $04(0.6 \%)$ & $48(7.7 \%)$ & $138(22.3 \%)$ & $430(69.4 \%)$ & 3.60 & 0.66 \\
\hline $\begin{array}{l}\text { I keep professional knowledge } \\
\text { and skills up-to-date }\end{array}$ & $06(1.0 \%)$ & $24(3.9 \%)$ & $203(32.8 \%)$ & $385(62.3 \%)$ & 3.56 & 0.62 \\
\hline $\begin{array}{l}\text { I have the knowledge of drugs } \\
\text { classification }\end{array}$ & $06(1.0 \%)$ & $24(4.0 \%)$ & $205(33.8 \%)$ & $372(61.3 \%)$ & 3.55 & 0.62 \\
\hline $\begin{array}{l}\text { I carry out admission of } \\
\text { patients in my hospital }\end{array}$ & $19(3.0 \%)$ & $25(3.9 \%)$ & $208(32.7 \%)$ & $384(60.4 \%)$ & 3.50 & 0.71 \\
\hline I diagnose micro system issues & $10(1.7 \%)$ & $\begin{array}{l}103 \\
(17.1 \%)\end{array}$ & $184(30.5 \%)$ & $307(50.7 \%)$ & 3.30 & 0.81 \\
\hline
\end{tabular}

\section{Non-job task proficiency}

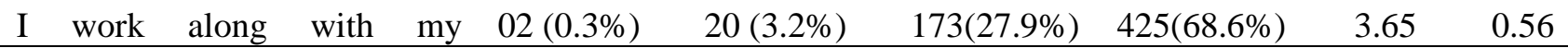


Maria Ehioghae, Ezinwanyi Madukoma and Vincent E. Unegbu: Job performance of resident doctors in government teaching hospitals in South-western Nigeria

\begin{tabular}{|c|c|c|c|c|c|c|}
\hline I demonstrate honesty at work & $02(0.3 \%)$ & $28(4.5 \%)$ & $159(25.6 \%)$ & $433(69.6 \%)$ & 3.64 & 0.58 \\
\hline $\begin{array}{l}\text { I treat patients with respect in } \\
\text { the hospital }\end{array}$ & $02(0.3 \%)$ & $28(4.4 \%)$ & $169(26.6 \%)$ & $437(68.7 \%)$ & 3.64 & 0.58 \\
\hline $\begin{array}{l}\text { I am approachable to my } \\
\text { patients }\end{array}$ & $08(1.3 \%)$ & $34(5.5 \%)$ & $132(21.4 \%)$ & $442(71.8 \%)$ & 3.64 & 0.65 \\
\hline $\begin{array}{l}\text { I communicate effectively with } \\
\text { patients }\end{array}$ & $04(0.6 \%)$ & $34(5.5 \%)$ & $161(25.9 \%)$ & $423(68.0 \%)$ & 3.61 & 0.62 \\
\hline $\begin{array}{l}\text { I have respect for patients' } \\
\text { confidentiality }\end{array}$ & $08(1.3 \%)$ & $35(5.6 \%)$ & $153(24.7 \%)$ & $424(68.7 \%)$ & 3.60 & 0.66 \\
\hline $\begin{array}{l}\text { I show empathy to patients } \\
\text { constantly }\end{array}$ & & $28(4.4 \%)$ & $219(34.4 \%)$ & $389(61.2 \%)$ & 3.57 & 0.58 \\
\hline $\begin{array}{l}\text { I give individual attention to } \\
\text { patients }\end{array}$ & $02(0.3 \%)$ & $28(4.5 \%)$ & $226(36.6 \%)$ & $362(58.6 \%)$ & 3.53 & 0.60 \\
\hline $\begin{array}{l}\text { I encouragepatients in the } \\
\text { hospital to build confidence }\end{array}$ & & $51(8.0 \%)$ & $201(31.6 \%)$ & $384(60.4 \%)$ & 3.52 & 0.64 \\
\hline $\begin{array}{l}\text { I support other doctors to } \\
\text { perform their job }\end{array}$ & $10(1.6 \%)$ & $32(5.0 \%)$ & $213(33.6 \%)$ & $379(59.8 \%)$ & 3.52 & 0.67 \\
\hline $\begin{array}{l}\text { I have the knowledge of data } \\
\text { analysis }\end{array}$ & $14(2.3 \%)$ & $\begin{array}{l}129 \\
(21.2 \%)\end{array}$ & $273(44.8 \%)$ & $193(31.7 \%)$ & 3.06 & 0.77 \\
\hline
\end{tabular}

\section{Group Mean $=3.55$}

\section{$\mathrm{N}=636$}

Decision Rule: The decision rule states that: 1.0-1.49 = Very low level of job performance; 1.50-2.49 = Low level of job performance; $2.50-3.49=$ High level of job performance; $3.50-$ $4.0=$ Very high level of job performance. Criteria mean of 2.5 is calculated as follows: $4+3+2+1=10 / 4=2.5$.

The result in Table 2 shows that the level of job performance of resident doctors in teaching hospitals in Southwestern Nigeria was very high as indicated by the grand mean score of 3.57 based on the decision rule stated. The result reveals the frequency counts, percentage, mean and standard deviations for each item in resident doctors' job performance. The group mean for each job performance indicators and the grand mean for job performance were calculated. Resident doctors' job performance is divided into two dimensions namely job task proficiency and non-job task proficiency as guided by Campbell's (1990) theory in the literature review. Each of the dimensions had statements under them which resident doctors responded to. The table shows the mean score of the responses to each statement.

Job task proficiency had a group mean score of 3.59. This shows that the level of job task proficiency of resident doctors in teaching hospitals in Southwestern Nigeria was very high. Nonjob task proficiency had a group mean score of 3.55. This shows that the level of non-job task proficiency of resident doctors in teaching hospitals in SouthWest, Nigeria was also very high. The findings also show that job task proficiency made agreater contribution to job performance while non-job task 
Maria Ehioghae, Ezinwanyi Madukoma and Vincent E. Unegbu: Job performance of resident doctors in government teaching hospitals in South-western Nigeria

proficiency offered less contribution. The findings imply that resident doctors are more effective in the aspect of job task proficiency than non-job task proficiency in teaching hospitals in Southwestern Nigeria.

Specifically, under job task proficiency, resident doctors perceived very highly that they carry out a physical examination of patients in their hospitals (mean=3.72) while they also feel on a high level, that they diagnose microsystem issues $($ mean $=3.30)$, though this was considered to be the lowest under job task proficiency measurement. This finding may imply that resident doctors in teaching hospitals in Southwestern Nigeria are highly effective in diagnosing patients who come for medical consultations. In addition to this, other statements showed very high levels of job task proficiency. This may boost a high level of job productivity of resident doctors of teaching hospitals in South-West, Nigeria.

Under non-job task proficiency, though it has the lower contributions in job performance, its mean score was 3.55. Specifically, resident doctors perceived very highly that they work along with colleagues in the hospital (mean=3.65), but their knowledge of data analysis though high (mean=3.06), was considered to be the lowest under non-job task proficiency measurement. Additionally, the remaining statements showed a very high level of perception regarding non-job task proficiency.

Research question 3: What are the barriers to job performance of resident doctors in teaching hospitals in Southwestern Nigeria?

The data in Table 3 are used to answer this question 
Maria Ehioghae, Ezinwanyi Madukoma and Vincent E. Unegbu: Job performance of resident doctors in government teaching hospitals in South-western Nigeria

Table 2: Barriers to job performance of resident doctors in teaching hospitals

\begin{tabular}{|c|c|c|c|c|c|c|}
\hline $\begin{array}{l}\text { Barriers to Job } \\
\text { Performance }\end{array}$ & $\begin{array}{l}\text { Strongly } \\
\text { Agree }\end{array}$ & Agree & Disagree & $\begin{array}{l}\text { Strongly } \\
\text { Disagree }\end{array}$ & Mean & Std \\
\hline Staff shortages & $407(66.5 \%)$ & $128(20.9 \%)$ & $54(8.8 \%)$ & $23(3.8 \%)$ & 3.50 & 0.81 \\
\hline $\begin{array}{l}\text { Lack of conducive } \\
\text { working environment }\end{array}$ & $362(58.8 \%)$ & $142(23.1 \%)$ & $84(13.6 \%)$ & $28(4.5 \%)$ & 3.36 & 0.88 \\
\hline $\begin{array}{l}\text { Inadequate equipment at } \\
\text { the teaching hospitals }\end{array}$ & $354(57.7 \%)$ & $147(23.9 \%)$ & $88(14.3 \%)$ & $25(4.1 \%)$ & 3.35 & 0.87 \\
\hline Long working hours & $340(55.6 \%)$ & $158(25.8 \%)$ & $89(14.5 \%)$ & $25(4.1 \%)$ & 3.33 & 0.87 \\
\hline $\begin{array}{l}\text { Limited access to } \\
\text { technology }\end{array}$ & $293(46.1 \%)$ & $243(38.2 \%)$ & $177(12.1 \%)$ & $23(3.6 \%)$ & 3.27 & 0.81 \\
\hline $\begin{array}{l}\text { Lack of advancement } \\
\text { opportunities }\end{array}$ & $236(37.2 \%)$ & $233(36.8 \%)$ & $142(22.4 \%)$ & $23(3.6 \%)$ & 3.08 & 0.86 \\
\hline Lack of mentoring & $191(30.0 \%)$ & $251(39.5 \%)$ & $172(27.0 \%)$ & $22(3.5 \%)$ & 2.96 & 0.84 \\
\hline Inadequate training & $163(26.5 \%)$ & $262(42.5 \%)$ & $152(24.7 \%)$ & $39(6.3 \%)$ & 2.89 & 0.87 \\
\hline $\begin{array}{l}\text { Poor interpersonal } \\
\text { relationship }\end{array}$ & $152(24.8 \%)$ & $211(34.3 \%)$ & $189(30.8 \%)$ & $62(10.1 \%)$ & 2.74 & 0.94 \\
\hline Disregard for safety & $180(29.6 \%)$ & $165(27.0 \%)$ & $182(29.8 \%)$ & $83(13.6 \%)$ & 2.72 & 1.03 \\
\hline $\begin{array}{l}\text { Insufficient time with the } \\
\text { patients }\end{array}$ & $122(19.8 \%)$ & $193(31.3 \%)$ & $235(38.2 \%)$ & $66(10.7 \%)$ & 2.60 & 0.92 \\
\hline & $141(23.3 \%)$ & $147(24.2 \%)$ & $218(36.0 \%)$ & $100(16.5 \%)$ & 2.54 & 1.02 \\
\hline $\begin{array}{l}\text { arainess } \\
\text { Doing task incorrectly }\end{array}$ & $117(19.0 \%)$ & $163(26.5 \%)$ & $248(40.2 \%)$ & $88(14.3 \%)$ & 2.50 & 0.96 \\
\hline $\begin{array}{l}\text { Poor communication } \\
\text { skills }\end{array}$ & $112(18.2 \%)$ & $165(26.8 \%)$ & $251(40.7 \%)$ & $88(14.3 \%)$ & 2.49 & 0.95 \\
\hline Absenteeism. & $120(19.7 \%)$ & $122(20.0 \%)$ & $229(37.5 \%)$ & $139(22.8 \%)$ & 2.37 & 1.04 \\
\hline \multicolumn{7}{|c|}{ Mean $=2.93$} \\
\hline
\end{tabular}

$\mathrm{N}=636$

Respondents were asked to indicate the barriers to the job performance of resident doctors in teaching hospitals in SouthwesternNigeria. Table 2 reveals that staff shortages (mean $=3.50$ ) were a major barrier encountered by resident doctors regarding their job performance. This was followed by lack of conducive working environment (mean=3.36), inadequate equipment at the teaching hospitals (mean=3.35), long working hours $($ mean $=3.33)$, limited access to technology (mean=3.27), lack of advancement opportunities (mean=3.08), lack of mentoring $\quad($ mean=2.96), inadequate training (mean=2.89), poor interpersonal relationship $($ mean $=2.74)$, disregard for safety (mean=2.72), insufficient time with 
Maria Ehioghae, Ezinwanyi Madukoma and Vincent E. Unegbu: Job performance of resident doctors in government teaching hospitals in South-western Nigeria

the patients (mean=2.60), tardiness (mean=2.54), and doing the task incorrectly $($ mean $=2.50)$. On the other hand, just a little below average expressed that poor communication skills $($ mean $=2.49) \quad$ and absenteeism (mean=2.37) were no barriers to resident doctors' job performance in teaching hospitals in Southwestern Nigeria. This result suggests that several challenges identified in this study may affect job performance of resident doctors if urgent interventions are not taken by teaching hospital administrators for a redress.

\section{Discussion}

The study examined the job performance of resident doctors in government teaching hospitals in the Southwestern Nigeria. The findings of this study indicate that resident doctors in government teaching hospitals in the study area scored high in job performance. Contrary to the findings of this research, the study carried out by Anyaehie, Anyaehie, Nwadinigwe, Emegoakor, Ogbu (2012) revealed that resident doctors performed below expectations. Their research report, however, did not take into consideration other factors like proficiency and the fact that residency is a training program which may have a determinative role in job performance. The rigorous training of doctors and a sense of responsibility to their work may account for high job performance.

Residency in government teaching hospitals is usually competitive and those who can get placement in such academic hospitals would expectedly want to demonstrate a high level of proficiency to justify the placement. The findings of a research carried out by Esan, Adeoye, Onakoya, Opeodu,Owonikoko, Olulana, Bello, Adeyemo, Onigbogi, Idowu and Akute (2014) corroborate the view that residency prioritizes service provision which emphasizes proficiency, sometimes at the expense of the high level of psychological distress on the part of the resident doctor. This is in line with this study where the resident doctors demonstrated a high level of task proficiency in their job performance. In congruence with this study, a research carried out by Obasohan and Ayodele (2014) on the assessment of job stress among clinical health workers in three selected health-care industries in Lagos state, Nigeria revealed that high job performance has its toll on resident doctors. The doctors were proficient but at a cost: stress and burnout.

In line with this study, the findings from the studies carried out by Ojo and Akinwumi (2015) on doctors as managers of healthcare resources in Nigeria and Bello, Ajayi and Asuzu (2018) on determinants of job satisfaction among physicians in public hospitals in Calabar, Nigeria showed that communication is an important element in doctors' job performance. Good communication enhances job performance.

Resident doctors in teaching hospitals in South-West Nigeria, like any other organization, cannot be said to be free from all the challenges that employees face in the workplace. This observation is concretized by the negative implications for job performance as reflected in the responses by the majority of the resident doctors to the quality of the workplace environment. In line with this study, the findings of a study by Ogunnubi, Ojo, Oyelohunnu, Olagunju and Tshuma (2018) on stress and training satisfaction among resident doctors in Nigeria showed that residency training is stressful for doctors which can have negative impacts not only on their physical and mental well-being but equally on patient care. As indicated in this study, long working hours is a major challenge for resident doctors and this invariably leads to excessive stress. Collaboratively, the report of a study by Obasohan and Ayodele (2014) on job stress among clinical health workers in 
Maria Ehioghae, Ezinwanyi Madukoma and Vincent E. Unegbu: Job performance of resident doctors in government teaching hospitals in South-western Nigeria

three selected health-care industries in Lagos State, Nigeria indicates that healthcare workers experienced one form of job strain or the other. The negative implication could be enormous in that it can lead to adverse effects on patient outcomes, patient safety as well as compromise quality care generally. Further, Esan, Adeoye, Onakoya, Opeodu, Owonikoko, Olulana, Bello,Adeyemo, Onigbogi, Idowu and Akute (2014) who reported on residency training and psychological distress among residents in a Nigerian teaching hospital revealed that the intensity of work was a major cause of psychological distress among resident doctors. There is little to doubt that excessive stress is not healthy both for the caregiver and the care receiver.

\section{Conclusion}

The study concludes that the job performance of resident doctors in the government teaching hospitals, SouthWest, Nigeria is high. There are, however, challenges that must be addressed to sustain the level of productivity among resident doctorsin the South-West Nigerian geopolitical zone. Some of these challenges include staff shortages, lack of conducive work environment, and long working hours. The job performance of the resident doctors may begin to decrease in due course if the challenges persist. Therefore, the following recommendations are set forth:

1. The management of government teaching hospitals should take urgent steps to redress the challenge posed by staff shortages that can affect the level of performance of resident doctors.

2. The workplace environment should also be improved. Workplace stressors such as long shifts, lack of resources, and heavy workloads have the potential of threatening the wellbeing of resident doctors and impinge negatively on their job performance.

3. The management should also, as a matter of policy, invest in the acquisition of new technology for more effective clinical diagnosis and treatment of diseases. This becomes imperative because of emerging diseases such as the new strain of coronavirus, otherwise known as COVID-19.

4. Finally, there is a need to provide advancement opportunities for resident doctors in the hospitals where they serve. By so doing, they will be motivated to scale up their performance.

\section{References}

Aacharya, R. P. \& Varghese, S. (2016). Medical doctors' strike: an ethical overview with reference to the Indian context. Journal of Clinical Research \& Bioethics, 7 (3), 272-286.

Akokuwebe, M. E. \&Adekanbi, D. M. (2017). Corruption in the health sector and implications for service delivery in Oyo State public hospitals. Ilorin Journal of Sociology, 9 (1), 200-217.

Alagaraja, M. \& Shuck, B. (2015). Exploring Organizational Alignment-Employee

Engagement Linkages and Impact on Individual Performance: A Conceptual Model. Human Resource Development Review, 14 (1), $17-37$.

Amudha, P., Hamidah, H., Annamma, K. \& Ananth, N. (2018). Effective Communication between Nurses and Doctors: Barriers as Perceived by Nurses. J Nurs Care, 7, 455. doi:10.4172/21671168.1000455 . 
Maria Ehioghae, Ezinwanyi Madukoma and Vincent E. Unegbu: Job performance of resident doctors in government teaching hospitals in South-western Nigeria

Anyaehie, U. E., Anyaehie, U. S. B., Nwadinigwe, C. U., Emegoakor, C. D. \&Ogbu, V. O. (2012). Surgical Resident Doctor's Perspective of Their Training in the Southeast Region of Nigeria. Annals of Medical and Health Sciences Research, 2 (1), DOI: 10.4103/2141-9248.96931

Bello, S., Ajayi, D. T. \&Asuzu, M. C. (2018). Determinants of job satisfaction among physicians in public hospitals in Calabar, Nigeria. Journal of Community Medicine and Primary Health Care, 30 (1), 34-39.

Campbell, J. P. (1990). Modelling the performance prediction problem in industrial and organizational psychology. In Dunnettee M. D., \& Hough, L. M. (eds.), Handbook

of industrial and organizational psychology (pp. 687-732). Palo Alto: Consulting Psychology Press, Inc.

Campbell, J. P. \& Wiernik, B. M.

(2015). The Modeling andAssessment of WorkPerformance.The Annual Review of Organizational

Psychology and

Organizational Behavior, 2, 47-74.

Douglas, G. Nicol, F. \& Robertson, C. (2011). MacLeod's clinical examination. New York: Churchhill Living Stone Elsevier.

Esan, O., Adeoye, A., Onakoya, P., Opeodu, O., Owonikoko, K., Olulana, D., Bello, M., Adeyemo, A., Onigbogi, L., Idowu, O. \&Akute, T. (2014). Features of residency training and psychological distress among residents in a Nigerian teaching hospital. $S$ Afr $J$ Psych., 20 (2), 46-50.

Graham, D. Fional, N. \& Colin, R. (Eds.), (2011). Macleod's Clinical Examination. London: Churchill Livingstone Elsevier.

Khalifa, M. (2014). Clinical decision support: Strategies for success. Procedia Computer Science, 37, 422-427.

Neeli, M., Leonard, L., Keith, A. \& William, L. (2006). Patients' perspectives on ideal physician behaviors. The Journal of Mayo Clinic Proceedings, 81 (3), 338344.

Obasohan, M. O. \& Ayodele, K. O. (2014). Assessment of Job Stress among Clinical Health Workers in Three Selected Health-Care Industries in Lagos State, Nigeria. Ife Psychologia, 22 (2), 58-67.

Ogunnubi, O. P., Ojo, T. M., Oyelohunnu, M. A., Olagunju, A. T. \& Tshuma, N. (2020). Stress and training satisfaction among resident doctors in Nigeria: Any justification for a change in training policy?.J Clin Sci., 15, 32-40.

Ojo, T. O. \&Akinwumi, A. F. (2015). Doctors as managers of healthcare resources in Nigeria: Evolving roles and current challenges, Niger Med J., 56 (6), 375-380.

Okorie, C. N. (2019). Organisational climate, movtivational factors, employee, commitment and job performance of library personal in Universities and Institutions of Agriculture in Nigeria. Ph.D Thesis (Unpublished).

Saka, K. A. \& Haruna, I. (2013). Relationship between staff 
Maria Ehioghae, Ezinwanyi Madukoma and Vincent E. Unegbu: Job performance of resident doctors in government teaching hospitals in South-western Nigeria

development and job performance among personnel in branch libraries, University of Maduguri, Nigeria. Mediterranean Journal of social sciences, 4 (5), 9-17.

Shaju, M. \& Subhashini, D. (2017). A study on the impact of Job Satisfaction on Job Performance of Employees working in Automobile Industry, Punjab, India. Journal of Management Research, 9 (1), 117-130.

Yakasai, I. A., Ugwa, E. A. \& Abubakar, I. S. (2013). Job satisfaction among resident doctors in a tertiary healthcare facility in Northern Nigeria. Trop J ObstetGynaecol, 30 (1), $456-474$

\footnotetext{
About the Authors

Maria Ehioghae is the Medical Librarian of Benjamin Carson Sr School of Medicine library, Ilishan-Remo, Ogun State, Nigeria. She holds a Bachelor's degree in Information Resources Management (BIRM) and a Masters' degree in Information Resources Management (MIRM), Babcock University, Ilishan-Remo, Ogun State, Nigeria. She is a member of the Medical Library Association, Nigeria (MLA-NG), Association for Health Information and Libraries in Africa - Nigerian Chapter (AHILA-NG), and the Nigerian Library Association (NLA), Nigeria. Her area of specialization is in health information management in librarianship. She may be reached at the following contacts: +2347034728537; E-mail: ehioghaem@babcock.edu.ng
}

Dr Ezinwanyi Madukoma teaches in the Department of Information Resources Management, Babcock University, IlishanRemo, Ogun State, Nigeria. She holds a Bachelor's degree in Information Resources Management (BIRM), a Masters' degree in Library and Information Science (MLIS), University of Ibadan, Oyo State, Nigeria, and a PhD in Information Resources Management, Babcock University, Ilishan-Remo, Ogun State, Nigeria. She is a member of Nigerian Library Association (NLA), Nigeria. Her area of specialization is in Library and Information studies. She may be reached at the following contacts: +234 8136232950; email:

madukumae@babcock.edu.ng.

Prof. Vincent Enyeribe Unegbu teaches in the Department of Information Resources Management, Babcock University, IlishanRemo, Ogun State, Nigeria. He holds a Bachelor of Arts (BA) degree in Religion, Andrews University, Berrien Springs, Michigan, USA, a Masters' degree in Library Science (MLS), University of Ibadan, Oyo State, Nigeria, and a PhD in Information Resources Management, Babcock University, Ilishan-Remo, Ogun State, Nigeria. He is a member of the Nigerian Library Association (NLA), Nigeria. His area of specialization is in Library and Information studies. He may be reached at the following contacts: +234 8131581233; E-mail: unegbuv@ babcock .edu.ng. 